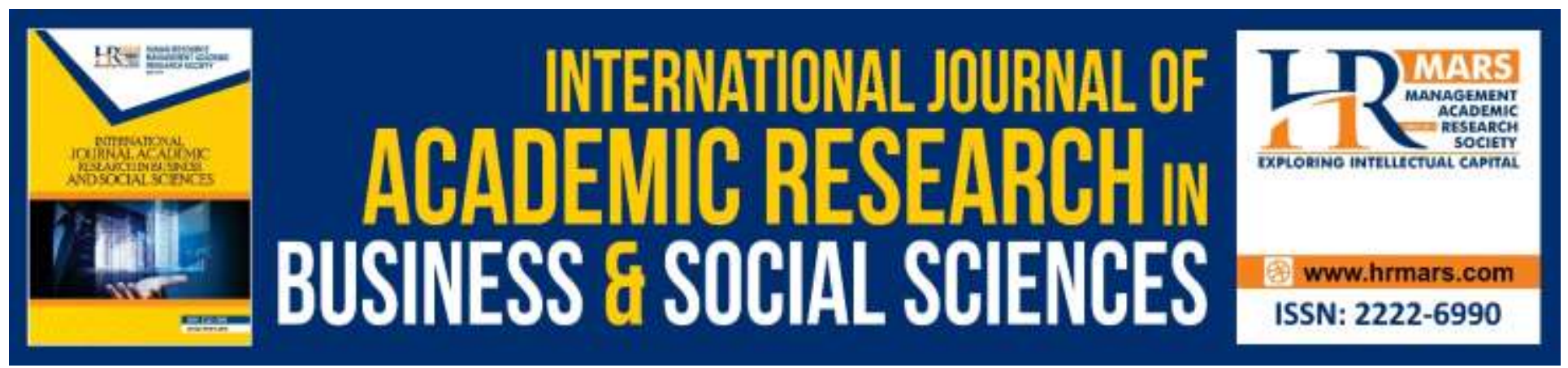

\title{
Factors Affecting Car Purchase Intention among Undergraduates in Malaysia
}

Tan Owee Kowang, Siti Aisyah Samsudin, Lim Kim Yew, Ong Choon Hee, Goh Chin Fei, Choi Sang Long

To Link this Article: http://dx.doi.org/10.6007/IJARBSS/v8-i8/4437

DOI: $10.6007 /$ IJARBSS/v8-i8/4437

Received: 13 July 2018, Revised: 29 July 2018, Accepted: 21 August 2018

Published Online: 24 August 2018

In-Text Citation: (Kowang et al., 2018)

To Cite this Article: Kowang, T. O., Samsudin, S. A., Yew, L. K., Hee, O. C., Fei, G. C., \& Long, C. S. (2018). Factors Affecting Car Purchase Intention among Undergraduates in Malaysia. International Journal of Academic Research in Business and Social Sciences, 8(8), 79-86.

Copyright: (c) 2018 The Author(s)

Published by Human Resource Management Academic Research Society (www.hrmars.com)

This article is published under the Creative Commons Attribution (CC BY 4.0) license. Anyone may reproduce, distribute, translate and create derivative works of this article (for both commercial and non-commercial purposes), subject to full attribution to the original publication and authors. The full terms of this license may be seen

at: http://creativecommons.org/licences/by/4.0/legalcode

Vol. 8, No. 8, August 2018, Pg. 79 - 86

http://hrmars.com/index.php/pages/detail/IJARBSS

JOURNAL HOMEPAGE

Full Terms \& Conditions of access and use can be found at http://hrmars.com/index.php/pages/detail/publication-ethics 


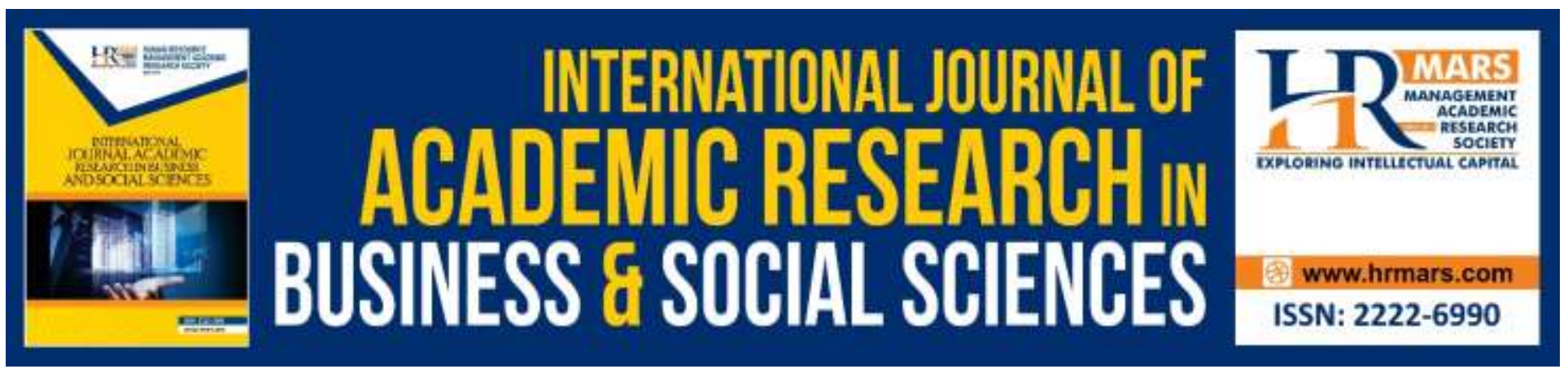

\title{
Factors Affecting Car Purchase Intention among Undergraduates in Malaysia
}

\author{
${ }^{1}$ Tan Owee Kowang, ${ }^{1}$ Siti Aisyah Samsudin, ${ }^{2}$ Lim Kim Yew, ${ }^{1}$ Ong \\ Choon Hee, ${ }^{1}$ Goh Chin Fei, ${ }^{3}$ Choi Sang Long \\ ${ }^{1}$ Azman Hashim International Business School, Universiti Teknologi Malaysia, Johor, Malaysia, ${ }^{2}$ INTI \\ International University, Nilai, Malaysia, ${ }^{3}$ Raffles University, Iskandar, Malaysia
}

Email: oktan@utm.my.

\begin{abstract}
Young graduates made up $15.6 \%$ of the overall employment population in Malaysia. Thus, the demand of new car purchase by young graduates in Malaysia constitutes an important market segment for automotive industry within the country. Hence, this research aims to explore the impact of new car purchase factors toward car purchase intention among final year undergraduates from the Faculty of Management (FM), Universiti Teknologi Malaysia. Four main car purchase factors were identified from literature review, which comprising of pricing, aesthetic, features and interpersonal influences. A total of 127 sets of questionnaires were distributed to the final year students from the Accounting, Marketing Management, Technology Management, Psychology and Human Resource Management undergraduate programs within FM, with 81 responded. Data collected were analysed using Multiple Regression analysis. Finding from the study reveals that $44.2 \%$ of the variation in car purchase intention among final year undergraduates of FM could be explained by the variation of the four car purchase factors. In addition, findings from the study also suggested that the impact of "aesthetic" toward car purchase intention is the highest among the four factors. The implication of the study is automobile industry shall place "aesthetic" as the marketing focus when dealing with market segment of young graduates.
\end{abstract}

Keywords: Car Purchase Intention, Price, Aesthetic, Features, Interpersonal Influences.

\section{Introduction}

Malaysia's automotive industry has been recognized as one of the most crucial industries for the nation. Automotive industry has been earmarked as mechanism to transform the nation to a better industrialization process as compared to other industries in the manufacturing sector in order for the country to become a developed nation in near future (Unescap, 2010). According to the data released by the Countrymeters (2017), young graduates working population made up $15.6 \%$ of overall employment in Malaysia. In addition, young graduates are having higher purchase power among young working adult, and they are the group of youngster who have higher potential and capable to 
own a car once step into the job market. Hence the demand of car by undergraduates or young graduates in Malaysia constituted an important market segment for automotive industry.

Car purchase intention had been studied by number of prior researchers (Dodds et. al. 1991; Schiffman and Kanuk, 2000; Bunnak, 2009; Shaharudin et al. 2011; Fung et al. 2012; Belgiawan et al. 2014; Lee and Govindan, 2014; Leow, \& Husin, 2015). However, most of the prior studies that related to car purchase intention were focusing on the general market segmentation, such as based on income and gender of the population. Study that focus on specific population such as young working adults or undergraduates are limited. From the perspective of young working adults or undergraduates, although there are few researches studied on the main factors that influence young adults purchase intention but the studies were focused on products such as apparels, fashion clothing and smartphones usage (Rajput et. al. 2012). Thus, this research is conducted in order to assess the impact of car purchase factors toward car purchase intention among undergraduates, with the focus on the final year undergraduates of the Faculty of Management (FM), Universiti Teknologi Malaysia (UTM). As such, the study aims to address two research objectives (RO);

R01: To assess the overall impact of car purchase factors toward car purchase intention among final year undergraduates in FM, UTM.

RO2: To evaluate the impact of individual car purchase factor toward car purchase intention among final year undergraduates in FM, UTM.

\section{Purchase Intention}

Purchase intention refers to the conscious plans of buying goods or services in the future based on the ability to commit (Warshaw and Davis, 1985). By identifying the intensity of the purchase intention, the likelihood of consumers to buy a product can be predicted, the stronger the purchase intention, the higher the chances of buying the products (Dodds et. al. 1991; Schiffman and Kanuk, 2000).

\section{Factors Affecting Car Purchase Intention}

Table 1 summarizes the finding from the literature review of factors affecting car purchase intention. As shown in Table 1, finding from literature review suggested that there are four most common factors proposed by prior researchers (Shaharudin et al. 2011; Fung et al. 2012; Belgiawan et al. 2014; Lee and Govindan, 2014; Leow, \& Husin, 2015) as the main factors affecting car purchase intention, which are pricing, aesthetic, features and interpersonal influence. 
INTERNATIONAL JOURNAL OF ACADEMIC RESEARCH IN BUSINESS AND SOCIAL SCIENCES Vol. 8, No. 8, August 2018, E-ISSN: 2222-6990 @ 2018 HRMARS

Table 1: Factors Affecting Car Purchase Intention

\begin{tabular}{|l|c|c|c|c|c|c|}
\cline { 2 - 7 } \multicolumn{1}{l|}{} & Price & Aesthetic & Features & $\begin{array}{c}\text { Interpersonal } \\
\text { Influence }\end{array}$ & Brand & Reliability \\
\hline Fung et. al. (2012) & $\mathrm{V}$ & $\mathrm{V}$ & $\mathrm{V}$ & $\mathrm{V}$ & & \\
\hline Shaharudin et al. (2011) & & $\mathrm{V}$ & $\mathrm{V}$ & & & \\
\hline Belgiawan et al. (2014) & & & $\mathrm{V}$ & $\mathrm{V}$ & & \\
\hline Lee and Govindan (2014) & $\mathrm{V}$ & & $\mathrm{V}$ & & & $\mathrm{V}$ \\
\hline $\begin{array}{l}\text { Leow, C. S., \& Husin, Z. } \\
\text { (2015) }\end{array}$ & $\mathrm{V}$ & $\mathrm{V}$ & $\mathrm{V}$ & $\mathrm{V}$ & $\mathrm{V}$ & \\
\hline TOTAL & $\mathbf{3}$ & $\mathbf{3}$ & $\mathbf{5}$ & $\mathbf{3}$ & $\mathbf{1}$ & $\mathbf{1}$ \\
\hline
\end{tabular}

\section{Pricing}

According to Jacob \& Olson (1977), pricing is an indication to excite user perceptions prior to the purchase of certain products, hence pricing could affects the psychological reactions of consumers toward the intention of purchase (Fung et. al. 2012). In addition, the study done by Wendy and Fader (2009) also demonstrated that the level of relationship between pricing and purchase intention relies on the appraisal of the product by the consumer. From car purchase perspective, prior researchers (Fung et al. 2012; Lee and Govindan, 2014; Leow, \& Husin, 2015) tended to agreed and suggested that pricing plays an essential role toward car purchase intention.

\section{Aesthetic}

Aesthetic is associated with how an individual use their five sensory inputs to recognize or make contemplation on a product (Daviid and Glore, 2010). According to Bunnak (2009), the attractiveness of a product design is relying on the physical look configuration and the visual characteristic itself, which namely, is the aesthetic of the product. Within the context of car's aesthetic, the elements of aesthetic should have a sense that could enhance the relevancy in consumption interaction (Bunnak, 2009). It composed of aesthetic and symbolic valuing for consumers to measure the functional attributes and perceived ease to use (Marielle and Jan, 2005; Leow, \& Husin, 2015).

\section{Features}

Features of a product refers to the functionality of a product that able to perform according to the consumer's needs and expectation, at the meantime leading to the consumers' intention to purchase (Belgiawan et al. 2014). From car feature design perspective, prior studies suggested that the most important car features that expected by consumers consists of three aspects, which are adjustability, visibility and accessibility of the feature design (Zhan and Vrkljan, 2010). Hence, car makers who are competent to design and offering such feature design would be able to gain and sustain competitive advantage in the car market segment (Goldenberg et. al. 2003).

\section{Interpersonal Influence}

Interpersonal influence refers the positive effect toward purchase intention that driven by personal opinion (Fung et. al., 2012). Studies by prior researchers suggested that there are three sources of interpersonal influence toward purchase intention, which are influence by the innovator of the car, influence from the market maven and product leader (i.e. lead user) (Friek and Price, 1987). 
INTERNATIONAL JOURNAL OF ACADEMIC RESEARCH IN BUSINESS AND SOCIAL SCIENCES Vol. 8, No. 8, August 2018, E-ISSN: 2222-6990 @ 2018 HRMARS

Interpersonal influence is recognized as the essential factor to give an impact towards the purchase intention of cars (Kasi, 2017). Hence, product information that integrated with expert opinion and positive feedback from lead user will promote higher intention of purchase (Cohen et. al. 2010).

\section{Research Framework}

The research framework for this study is developed based on the concept that the four car purchase factors identified in the literature review have direct impacts toward car purchase intention. Figure 1 presents the research framework between price, aesthetic, features and interpersonal influences and purchase intention.

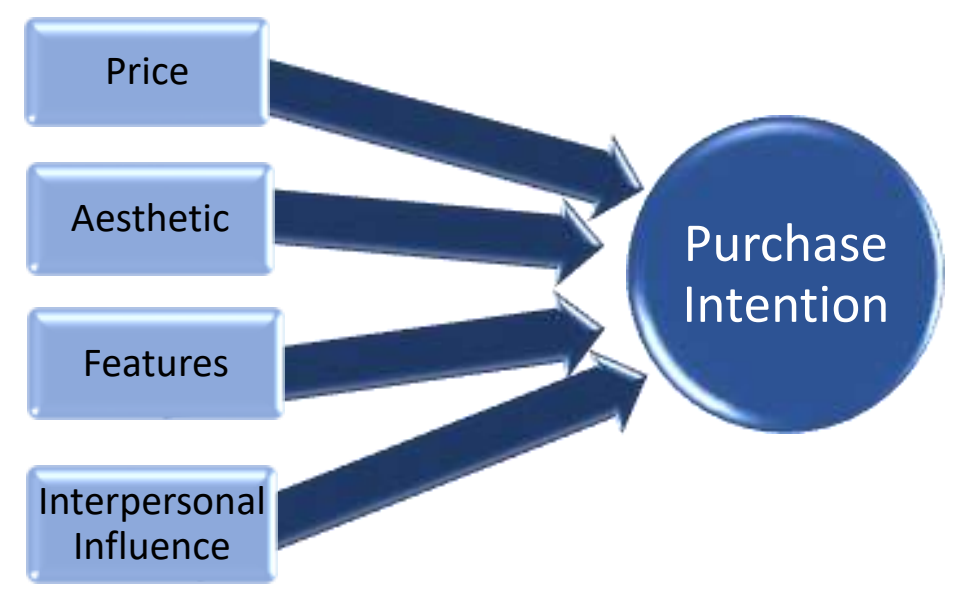

Figure 1: Research Framework

The research hypothesis for this study were developed as below:

H1: At least one of the car purchase factors affects car purchase intention among undergraduates in FM.

\section{Population and Sampling}

The target population in this research is the final year undergraduates of Faculty Management in Universiti Teknologi Malaysia, which consist of 127 respondents from Accounting, Marketing Management, Technology Management, Psychology and Human Resource Management undergraduate programs. The research instrument used in this research is self-completion survey. Questionnaire in the form of online survey are distributed to all 127 students.

\section{Data Analysis and Finding}

Data collected were analyzed via Statistical Package for Social Science (SPSS) Version 22. A total of 127 questionnaires were distributed with 81 responded which contributed a respond rate of $63.77 \%$. The value of Skewness and Kurtosis of all variables are within -2 and +2 suggested that data collected is normally distributed (Hair et. al. 2010). In addition, in term of reliability test, the Cronbach's Alpha for all the variables are above 0.60 suggests that data collected can be proceed for further analysis (Hair et. al. 2010). 
INTERNATIONAL JOURNAL OF ACADEMIC RESEARCH IN BUSINESS AND SOCIAL SCIENCES

Vol. 8, No. 8, August 2018, E-ISSN: 2222-6990 C 2018 HRMARS

Multiple Regression analysis is applied to address research objective 1 and 2. Table 2 and 3 summarized the analysis result from Multiple Regression analysis that addressing RO1.

Table 2: ANOVA of Multiple Regression

\begin{tabular}{|c|c|c|c|c|c|c|}
\hline \multicolumn{2}{|c|}{ Model } & Sum of Squares & $\mathrm{df}$ & Mean Square & $\mathrm{F}$ & Sig. \\
\hline 1 & Regression & 10.618 & 4 & 2.654 & 14.574 & $.000^{\mathrm{a}}$ \\
\hline & Residual & 13.842 & 76 & .182 & & \\
\hline & Total & 24.460 & 80 & & & \\
\hline
\end{tabular}

a. Predictors: (Constant), AvellnterInflu, AveFeatures, AveAesthetic, AvePrice

b. Dependent Variable: Purchase Intention

Table 3: Multiple Regression Model Summaries

\begin{tabular}{|l|l|l|l|l|}
\hline Model & $R$ & R Square & Adjusted R Square & $\begin{array}{l}\text { Std. Error of the } \\
\text { Estimate }\end{array}$ \\
\hline 1 & $.659^{\mathrm{a}}$ & .434 & .404 & .42677 \\
\hline
\end{tabular}

Based on the result of the Table 2, all the four factors that influences car purchase intention, i.e. the four predictors of pricing (AvePrice), aesthetic (AveAesthetic), features (AveFeatures) and interpersonal influence (Avelnterlnflu) are included in the model as predictors for car purchase intention. In addition, the significance level (i.e. sig) of " 0 " suggested there is sufficient evident to concluded that all the four factors are statistically significant to predict car purchase intention, hence, hypothesis $1(\mathrm{H} 1)$ is supported.

In addition, the $\mathrm{R}$ square value of 0.434 in Table 3 suggested that $43.4 \%$ of the variation in car purchase intention among final year undergraduates of Faculty of Management, UTM could be explained by the variation of the four car purchase factors, which are pricing, aesthetic, features and personal influences.

Table 4: Multiple Regression Coefficient

\begin{tabular}{|c|c|c|c|c|c|}
\hline \multirow[t]{2}{*}{ Model } & \multicolumn{2}{|c|}{$\begin{array}{l}\text { Unstandardized } \\
\text { Coefficients }\end{array}$} & \multirow{2}{*}{\begin{tabular}{|c|}
$\begin{array}{l}\text { Standardized } \\
\text { Coefficients }\end{array}$ \\
Beta \\
\end{tabular}} & \multirow[b]{2}{*}{$\mathrm{t}$} & \multirow[b]{2}{*}{ Sig. } \\
\hline & B & Std. Error & & & \\
\hline $1 \quad$ (Constant) & .681 & .428 & & 1.593 & .115 \\
\hline Price & .181 & .079 & .215 & 2.280 & .025 \\
\hline Aesthetic & .295 & .082 & .331 & 3.608 & .001 \\
\hline Features & .207 & .083 & .236 & 2.487 & .015 \\
\hline Interpersonal Influence & .187 & .066 & .257 & 2.817 & .006 \\
\hline
\end{tabular}

a. Dependent Variable: Purchase Intention 
INTERNATIONAL JOURNAL OF ACADEMIC RESEARCH IN BUSINESS AND SOCIAL SCIENCES

Vol. 8, No. 8, August 2018, E-ISSN: 2222-6990 @ 2018 HRMARS

Table 4 summarized Multiple Regression result of analysis to address RO2. Base on Table 4, the significant level (i.e. sig) for all predictors (i.e. all car purchase factors) are below 0.05 . This suggests that at significant level of 0.05 , all predictors are explanatory to car purchase intention. In addition, the standardized beta for Aesthetic is the highest at the level of 0.331, this reveals that Aesthetic makes the strongest unique contribution to explaining the car purchase intention. While standardized beta for pricing is the lowest at the level of 0.215 .

The finding from this study is in line with research done by Wayne \& Nicola (2011) which stated that aesthetic of car influenced consumer judgment toward the car's quality and desirability. The finding is also in parallel with study conducted by David and Glore (2010) which revealed that aesthetic judgments could impact the perceived usability aspects of a product.

\section{Conclusion}

Finding from this study reveals that the overall impact of the four car purchase factors (pricing, aesthetic, features and interpersonal influence) toward car purchase intention are significant. In addition, finding from the study also suggests that final year undergraduates in FM viewed aesthetic, i.e. the physical look configuration or visual characteristic of car as the most important factor that influence car purchase intention. Meantime, finding from the study also reveals that car purchase intention by final year undergraduates is less influenced by the pricing factor. The implication of the study is automobile industry shall place "aesthetic" as the marketing focus when dealing with car marketing strategy for young graduates

\section{Acknowledgements}

Authors wish to acknowledge the Malaysian Ministry of Higher Education and Universiti Teknologi Malaysia under the Research Grant (Vote No. 18H59) for sponsoring this publication.

\section{References}

Belgiawan, P. F., Schm€ocker, J. D., Abou-Zeid, M., Walker, J., \& Lee, T. C. (2014). Car Ownership Motivations among Undergraduate students in China, Indonesia, Japan, Lebanon, Netherlands, Taiwan and U.S.A. Transportation, 41(6), 1227-1244.

Bunnak, V. (2009). The Influence of Personal Values on Environmental Attitude, Product Aesthetics, and Product Evaluation. Marshal Goldmith School of Management, 39(4). 119-121.

Countrymeters. (2017). Malaysia Population Clock March 2017. Malaysia Population. Retrieved from http://countrymeters.info/en/Malaysia.

Cohen, M. J., Brown, H. S., \& Vergragt, P. J. (2010). Individual Consumption and Systematic Societal Transformation: Introduction to the Special Issue. Sustainability: Science, Practice \& Policy, 6(2), 1-12.

David, A., \& Glore, P. (2010). The Impact of Design and Aesthetics on Usability, Credibility and Learning in an Online. Journal of Distance Learning Administration. 13(4). Retrieved from http://www.westga.edu/ distance/ojdla/winter134/david_glore134.html.

Dodds, W. B., Monroe, K. B., \& Feick, L. F., \& Price, L. L. (1987). The Market Maven: A Diffuser of Marketplace Information. Journal of Marketing, 51, 83-97.

Dodds, W. B., Monroe, K. B., and Grewal, D. (1991) Effects of Price, Brand, and Store Information on Buyers' Product Evaluations. Journal of Marketing Research, 38, 307-326. http://dx.doi.org/10.2307/3172866. 
INTERNATIONAL JOURNAL OF ACADEMIC RESEARCH IN BUSINESS AND SOCIAL SCIENCES

Vol. 8, No. 8, August 2018, E-ISSN: 2222-6990 @ 2018 HRMARS

Fung, A. N. W., Jung, G. L. W., Ying, K. K., \& Wai, M. C. K. (2012). Factors that Affect the Purchasing Decision of Cars among Generation $Y$ Females. Bachelor Degree. Universiti Tunku Abdul Rahman (UTAR), Sungai Long.

Goldenberg, J., Horowitz, R., Levav, A., \& Mazursky, D. (2003). Finding Your Innovation Sweet Spot. Harvard Business Review, 81, 120-29.

Grewal, D. (1991). Effects of Price, Brand, and Store Information on Buyers' Product Evaluations. Journal of Marketing Research, 28(3), 307-319.

Hair, J. F., Jr., Black, W. C., Babin, B. J., \& Anderson, R. E. (2010). Multivariate data analysis: A global perspective ( $7^{\text {th }}$ ed.). Upper Saddle River, New Jersey: Pearson Education, Inc.

Jacob, J., \& Jerry, C. O. (1977). Consumer Response to Price: Attitudinal, Information Processing Perspective ( $1^{\text {st }}$ ed.). Pennsylvania State: University Park, Pa.

Kasi, K. (2017). Interpersonal Influence and Consumer Behavior. Consumer Behavior. Retrieved from http://marketingmixx.com/consumer-behavior-2/89-interpersonal-influence-and-consumer behavior.html.

Lee, T. W., \& Govindan, S. (2014). Emerging Issues in Car Purchasing Decision. Academic Research International, 5(5), 169-179.

Leow, C. S., \& Husin, Z. (2015). Product and Price Influence on Cars Purchase Intention in Malaysia. International Research Journal of Interdisciplinary \& Multidisciplinary Studies, 1(7), 108-119.

Marielle, E. H., \& Jan, P. L. (2005). The Different Roles of Product Appearance in Consumer Choice. Journal of Product Innovation Management, 22, 63-81.

Rajput, D. A., Kalhooro, S. H., \& Wasif, R. (2012). Impact of Product Price and Quality on Consumer Buying Behavior: Evidence from Pakistan, Journal of Contemporary Research in Business, 4(4), 485-496.

Schiffman, L. G., \& Kanuk, L. L. (2000). Consumer Behavior (7th ed.). Wisconsin: Prentice Hall.

Shaharudin, M. R., Mansor, S. W., Hassan, A. A., Omar, M. W., \& Harun, E. H. (2011). The relationship between Product Quality and Purchase Intention: The case of Malaysia's national motorcycle/scooter manufactuerer. African Jouranl of Business Management, 5(10), 81638176.

Warshaw, P. R., \& Davis, F. D. (1985). Disentangling Behavioral Intentions and Behavioral Expectations. Journal of Experimental Social Psychology, 21, 213-228.

Wayne, D. H., \& Nicola, E. S. (2011). The Role of Aesthetic Taste in Consumer Behaviour. Journal of Academic Marketing Science, 40, 167-180.

Wendy W. M., \& Fader, P. S. (2009). The Role of Price Tiers in Advance Purchasing of Event Tickets. Journal of Service Research, 12(1), 73-86.

Zhan, J., \& Vrkljan, B. (2010). Exploring Factors that Influences Vehicle Purchase Decisions of Older Drivers: Where does Safety Fit? Lowa Research Online. Retrieved from https://ir.uiowa.edu/cgi/viewcontent.cgi?article=1384\&context=drivingassessment. 